\title{
Traditional knowledge regarding edible insects in Burkina Faso
}

\author{
Aminata Séré1, Adjima Bougma', Judicaël Thomas Ouilly', Mamadou Traoré², Hassane Sangaré', \\ Anne Mette Lykke ${ }^{3}$, Amadé Ouédraogo ${ }^{4}$, Olivier Gnankiné ${ }^{5}$ and Imaël Henri Nestor Bassolé ${ }^{* *}$
}

\begin{abstract}
Background: Insects play an important role as a diet supplement in Burkina Faso, but the preferred insect species vary according to the phytogeographical zone, ethnic groups, and gender. The present study aims at documenting indigenous knowledge on edible insects in Burkina Faso.

Methods: A structured ethno-sociological survey was conducted with 360 informants in nine villages located in two phytogeographical zones of Burkina Faso. Identification of the insects was done according to the classification of Scholtz. Chi-square tests and principal component analysis were performed to test for significant differences in edible insect species preferences among phytogeographical zones, villages, ethnic groups, and gender.

Results: Edible insects were available at different times of the year. They were collected by hand picking, digging in the soil, and luring them into water traps. The edible insects collected were consumed fried, roasted, or grilled. All species were indifferently consumed by children, women, and men without regard to their ages. A total of seven edible insect species belonging to five orders were cited in the Sudanian zone of Burkina Faso. Macrotermes subhyalinus (Rambur), Cirina butyrospermi (Vuillet, 1911), Kraussaria angulifera (Krauss, 1877), Gryllus campestris (Linnaeus, 1758), and Carbula marginella (Thunberg) (35.66-8.47\% of the citations) were most cited whereas Rhynchophorus phoenicis (Fabricius, 1801) and Oryctes sp. (3.41-0.27\%) were least cited. Cirina butyrospermi was most cited in the South Sudanian zone, whereas Macrotermes subhyalinus and Kraussaria angulifera were most cited in the North Sudanian zone but were cited in all nine villages. Cirina butyrospermi was preferred by Bobo, Guin, Sambla, Senoufo, and Turka ethnic groups whereas Macrotermes subhyalinus was preferred by Fulani, Mossi, and Toussian ethnic groups. Oryctes sp. was cited only by the Toussian.
\end{abstract}

Conclusion: A diversity of edible insects was consumed in both the South and North Sudanian zone of Burkina Faso with significant differences in species preferences according to phytogeographical zones, villages, ethnic groups, and gender.

Keywords: Africa, Edible insects, Entomophagy, Local knowledge

\section{Background}

The world consumption of meat was $41.2 \mathrm{~kg} /$ person/year in 2005 with a variation in developing countries from 82.1 to $13.3 \mathrm{~kg}$ in Sub-Saharan Africa [1]. From 2005 to 2050, world consumption of meat is predicted to increase $76 \%$ [1]. However, this increased consumption of meat has implications for habitat destruction, climate change, and human health [2,3]. Alternative sources of animal proteins

\footnotetext{
* Correspondence: ismael.bassole@gmail.com

${ }^{1}$ Département de Biochimie Microbiologie, Université Ouaga I Professeur

Joseph KI-Zerbo, 03 BP 7021, Ouagadougou 03, Burkina Faso

Full list of author information is available at the end of the article
}

are highly needed. Among the sound alternatives, edible insects could occupy a prominent place. More than 2000 species of edible insects belonging to the orders of Coleoptera (beetles, often the larvae) (31\%), Lepidoptera (caterpillars) (17\%), Hymenoptera (wasps, bees, and ants) (15\%), Orthoptera (crickets, grasshoppers, and locusts) (14\%), Hemiptera (true bugs) (11\%), Isoptera (termites) (3\%), Odonata (dragonflies), Diptera (flies), and others (9\%) have been worldwide reported by Jongema et al. [4]. The use of insects as an alternative source of protein has many advantages when compared with animals traditionally bred for food, as insects have a high feed conversion rate [5]. On

(c) The Author(s). 2018 Open Access This article is distributed under the terms of the Creative Commons Attribution 4.0 International License (http://creativecommons.org/licenses/by/4.0/), which permits unrestricted use, distribution, and 
average, $2 \mathrm{~kg}$ of food is needed to produce $1 \mathrm{~kg}$ of body mass in insects, whereas cattle require $8 \mathrm{~kg}$ of food to produce $1 \mathrm{~kg}$ of body mass [6]. Insects produce less greenhouse gases, use less water, and are less dependent on soil than conventional livestock [7, 8]. Unlike livestock, edible insects transmit only rather few known zoonotic diseases to humans [9]. The consumption of insects does not present risks of carcinogenic and cardiovascular diseases [10].

Although nutritional value varies from one species to another, edible insects are good sources of protein, amino acids, fats, vitamins, and minerals for human dietary needs [11]. Some caterpillars contain $50-60 \mathrm{~g}$ protein per $100 \mathrm{~g}$ dry weight, the palm weevil grubs $23-36 \mathrm{~g}$, Orthoptera $41-91 \mathrm{~g}$, ants 7-25 g, and termites 35-65 g [12-18]. The average fat contents range from $13.41 \%$ for Orthoptera (grasshoppers, crickets, locusts) to $33.40 \%$ for Coleoptera (beetles, grubs) and nearly 50\% in Isoptera (termites) [11, 19, 20]. Analyses of nearly 100 species of edible insects have shown that the essential amino acid content is $10-30 \%$, covering $35-50 \%$ of all types of amino acids, close to the amino acid consumption recommended by the World Health Organization and FAO [10, 19]. The fatty acids of insects are generally comparable to those of poultry and fish in terms of their degree of unsaturation [11]. Eggs, larvae, and pupae of honeybees have high amounts of vitamins $\mathrm{A}, \mathrm{B} 2$, and $\mathrm{C}$ to the extent of $12.44 \mathrm{mg}, 3.24 \mathrm{mg}$, and $10.25 \mathrm{mg} / 100 \mathrm{~g}$, respectively [21]. Edible insects have the potential to provide specific micronutrients such as potassium, calcium, iron, and magnesium $[12,22,23]$. Termites have high iron contents $[24,25]$. They contain more iron and calcium than beef, pork, and chicken [26]. Anthropo-entomophagy (eating of insects by humans) is practiced in 130 countries throughout the world by 3071 ethnic groups [27]. Edible species have been estimated at 679 in America, 524 in Africa, 349 in Asia, 152 in Australia, and 41 in Europe [28]. In Africa, there is a great variation in the number of edible species according the countries. Roulon-Doko [29] reported 96 edible species in the Central African Republic. In Nigeria, 23 edible species have been reported by Alamu et al. [12]. Riggi et al. [30] identified 29 arthropod species eaten in Benin. Ehounou et al. [31] described 9 edible species in the Ivory Coast. The most consumed insect species belong to Coleoptera, Hemiptera, Hymenoptera, Isoptera, Lepidoptera, and Orthoptera. A number of studies have reported differences between ethnic groups in the practice of entomophagy. Mofu-Gudur in Cameroon eat a number of grasshopper species (Acorypha picta (Krauss, 1877), Acorypha glaucopsis (Walker, 1870), Acrida bicolor (Thunberg, 1815)), which are not eaten by Hausas in Niger, and some insect species are consumed by Hausa people in Niger, which are not eaten by Mofu-Gudur [32, 33]. Riggi et al. [30] reported that the Waama ethnic group in the north of Benin preferentially consumed Coleoptera and Orthoptera in adult stage whereas Nagot and the Anii in the South preferred Orthoptera and Coleoptera only in the larval stage. In Burkina Faso, edible insects belonging to the orders of Orthoptera, Isoptera, and Lepidoptera are widely consumed [34]. However, available data on the distribution of the traditional knowledge regarding edible insects are very limited across the country, which is what led us to embark on this study.

\section{Methods \\ Study area}

The study was conducted from June to December 2015 and 2016 in nine villages across the Sudanian zone of Burkina Faso. They are Beregadougou, Dinderesso, Koro, Siniena, and Koumi located in the South Sudanian zone $\left(9^{\circ}-11^{\circ} 30^{\prime} \mathrm{N}\right)$ and Gampela, Kombissiri, Mogtedo, and Zitenga in the North Sudanian zone $\left(11^{\circ} 30^{\prime}-14^{\circ} \mathrm{N}\right.$ ) (Fig. 1). In both study zones, the climate is dry tropical with a unimodal rainy season that lasts from May to October $[35,36]$. Mean annual rainfall ranged from 600 to $900 \mathrm{~mm}$ in the North Sudanian zone and 900 to $1000 \mathrm{~mm}$ in the South Sudanian one [37]. The vegetation of the South Sudanian zone consists of a mosaic of savanna, dry forest, and patches of gallery forest and is characterized by Sudanian and Guinean species whereas the North Sudanian zone is dominated by savanna with annual growing grass, trees, and shrubs $[35,38,39]$.

\section{Data collection}

In each village, 40 informants were interviewed through individual semi-structured interviews. Members of all eight ethnic groups were interviewed in each village, when present. The 40 informants in each village included at least 30 natives of the zone and up to 10 non-natives without regarding their religious affiliation. Informants were between 15 and 65 years old. Informants were included in the questionnaire regardless of their education and occupation. A total of 186 men and 174 women were interviewed (Table 1). The questionnaire included the number of known edible insects, seasonal availability, stages of insects consumed, and modes of preparation. During interviews or at a suggested period, insect specimens were collected in bottles containing alcohol for identification using the Scholtz classification [40].

\section{Data analysis}

Chi-square analysis was used to determine whether there were statistically significant differences among zones, villages, ethnic group, and gender in knowledge and preference for edible insects. Statistical significance was tested at the 5\% level. Principal component analysis (PCA) was used to explore patterns and variation in preferences 


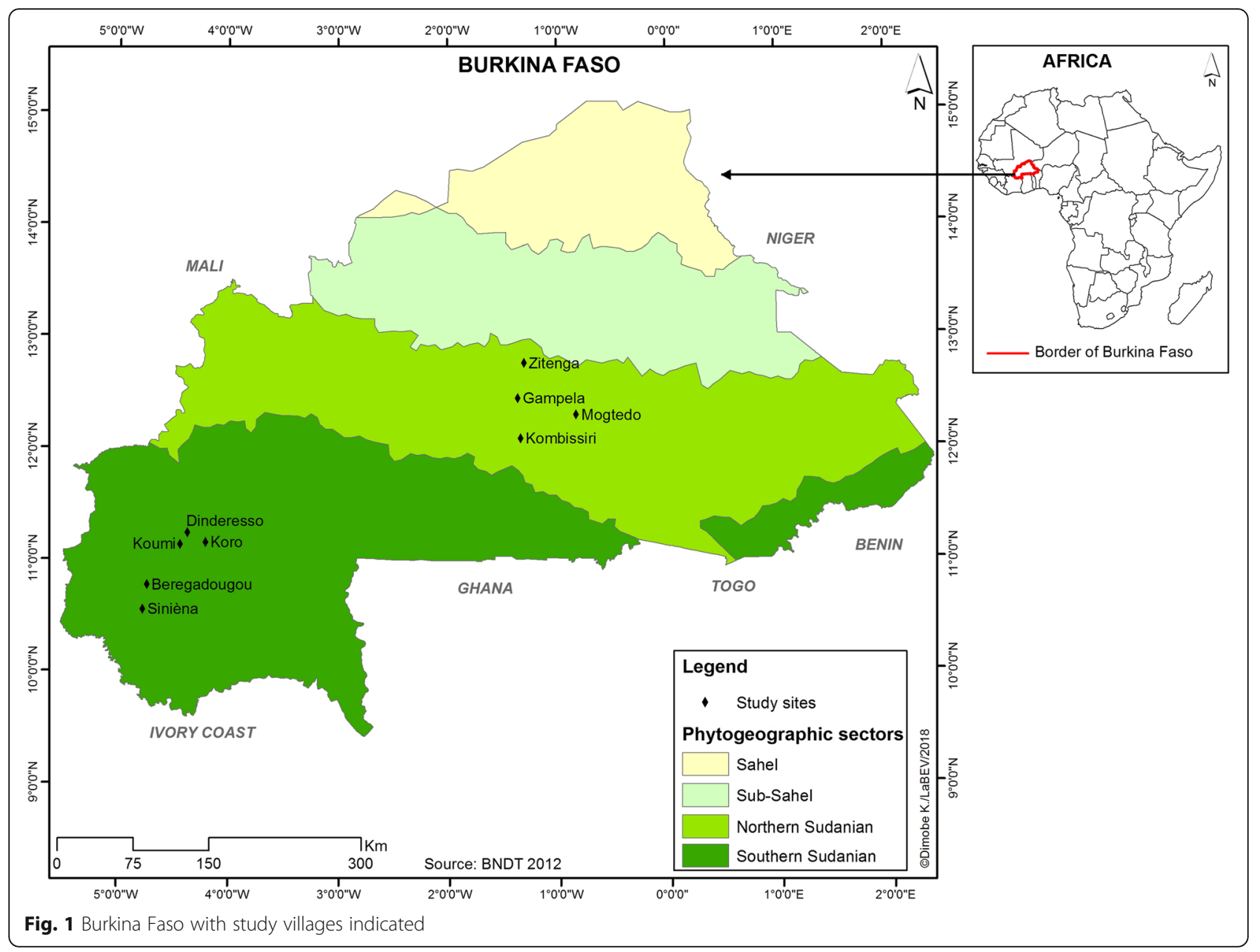

among zones, villages, and ethnic groups. The used statistical software was XLSTAT-Premium 2016.

\section{Results}

Local knowledge extent on edible insects in Burkina Faso Seven edible insect species belonging to five orders were cited as consumed in the nine villages (Fig. 2). They were not consumed at the same stage of development:
Macrotermes subhyalinus, Kraussaria angulifera, Gryllus campestris, and Carbula marginella were eaten at their adult stage whereas Cirina butyrospermi, Rhynchophorus phoenicis, and Oryctes sp. were eaten at the larval stage. Macrotermes subhyalinus, Cirina butyrospermi, and Kraussaria angulifera were the most cited whereas Rhynchophorus phoenicis and Oryctes sp. were the least cited (Fig. 3). 99.16\% of informants ate at least one insect species.

Table 1 Number of persons surveyed by ethnic group and village

\begin{tabular}{|c|c|c|c|c|c|c|c|c|c|c|}
\hline Phytogeographical zone & Villages & Bobo & Fulani & Guin & Mossi & Sambla & Senoufo & Toussian & Turka & Total \\
\hline South Sudanian & Beregadougou & 0 & 0 & 13 & 2 & 3 & 7 & 2 & 13 & 40 \\
\hline South Sudanian & Dinderesso & 17 & 0 & 0 & 6 & 0 & 5 & 12 & 0 & 40 \\
\hline South Sudanian & Koro & 13 & 0 & 2 & 9 & 4 & 6 & 4 & 2 & 40 \\
\hline South Sudanian & Koumi & 19 & 0 & 0 & 9 & 2 & 0 & 10 & 0 & 40 \\
\hline South Sudanian & Siniena & 0 & 0 & 9 & 10 & 3 & 6 & 0 & 12 & 40 \\
\hline North Sudanian & Gampela & 0 & 2 & 0 & 38 & 0 & 0 & 0 & 0 & 40 \\
\hline North Sudanian & Kombissiri & 0 & 6 & 0 & 34 & 0 & 0 & 0 & 0 & 40 \\
\hline North Sudanian & Mogtedo & 0 & 2 & 0 & 38 & 0 & 0 & 0 & 0 & 40 \\
\hline North Sudanian & Zitenga & 0 & 0 & 0 & 40 & 0 & 0 & 0 & 0 & 40 \\
\hline
\end{tabular}




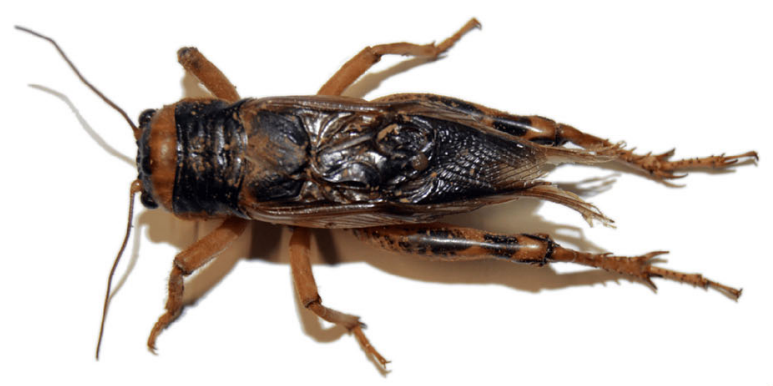

A. Gryllus campestris
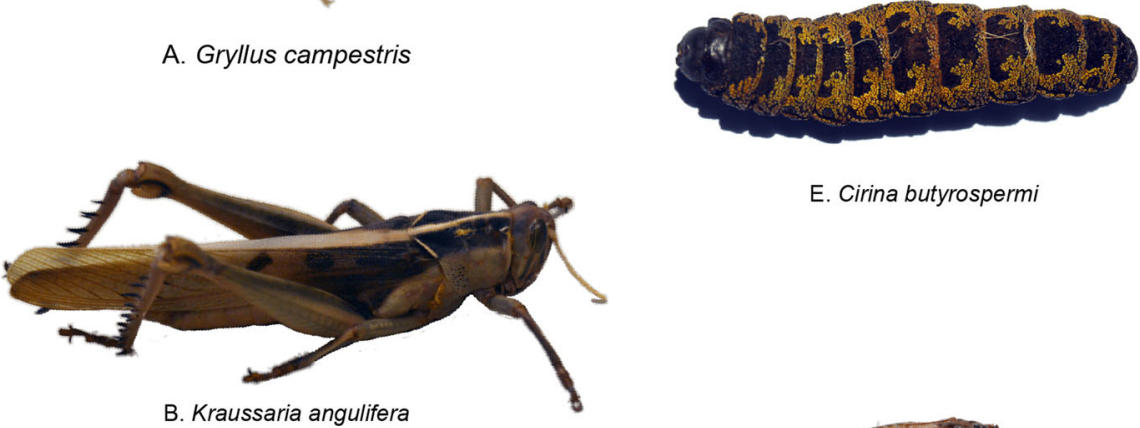

E. Cirina butyrospermi

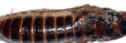

F. Macrotermes subhyalinus

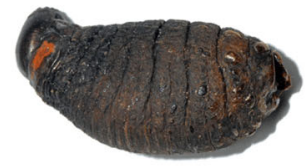

C. Rhynchophorus phoenicis

0

$40 \mathrm{~mm}$

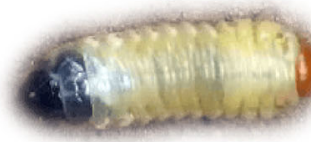

G. Oryctes sp.

Fig. 2 Edible insects across nine villages of Burkina Faso

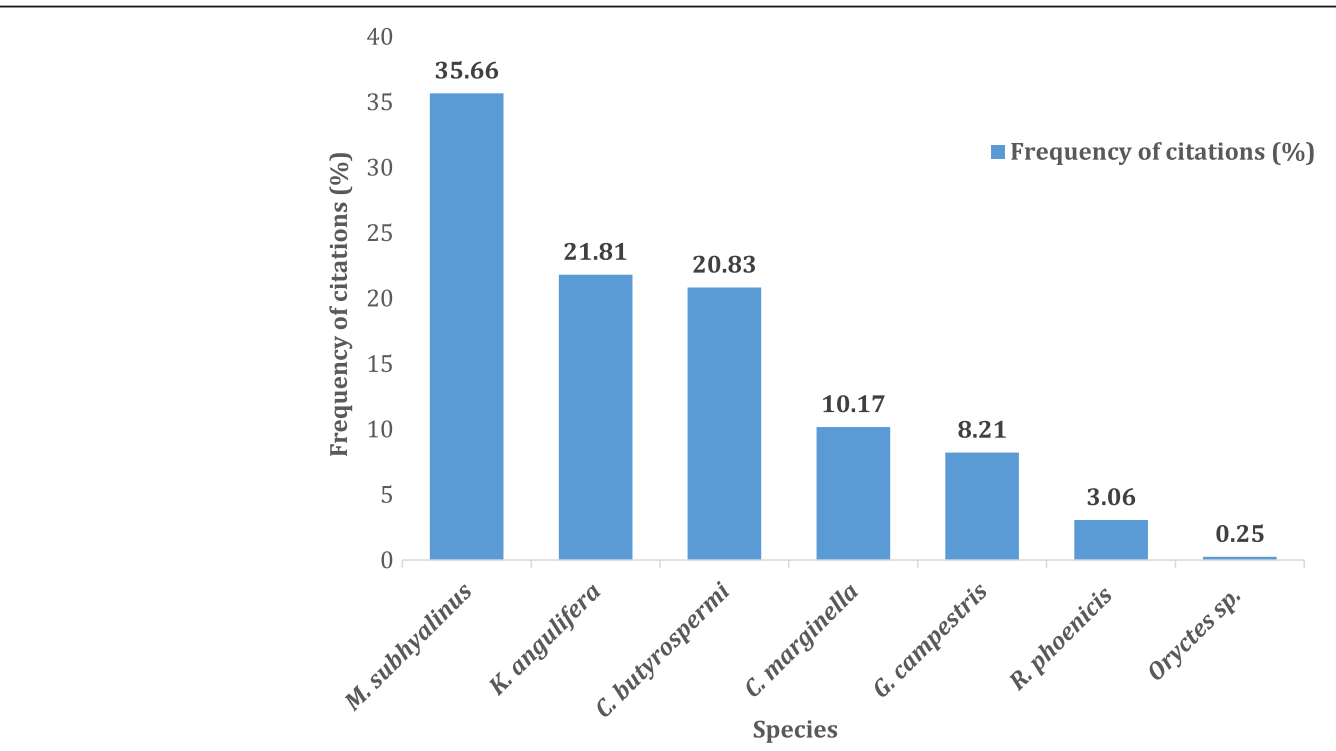

Fig. 3 The frequency of citations of edible insects in nine villages of Burkina Faso 
Significant differences were observed between zones, villages, ethnic groups, and gender.

\section{Distribution of cited edible insects according to phytogeographical zone}

The citations of edible insect species varied according to phytogeographic zone (Table 2). Four species were cited in both the South and North Sudanian zones, among them Cirina butyrospermi and Gryllus campestris were most cited in the South Sudanian zone whereas Kraussaria angulifera and Macrotermes subhyalinus were most cited in the North Sudanian zone. Rhynchophorus phoenicis and Oryctes sp. were exclusively cited in the South Sudanian zone while Carbula marginella was exclusive to the North Sudanian zone.

\section{Distribution of cited edible insects according to village} Macrotermes subhyalinus and Kraussaria angulifera were cited in all nine villages. Gryllus campestris, Rhynchophorus phoenicis, and Oryctes sp. were mentioned in eight, two, and one villages, respectively. Cirina butyrospermi and Carbula marginella were cited in three and four villages, respectively (Table 3).

In the North Sudanian zone, the consumption of the species Cirina butyrospermi, Carbula marginella, Gryllus campestris, and Macrotermes subhyalinus was significantly different among villages $\left(\left(X^{2}=21.96\right.\right.$; $\mathrm{df}=3$; $p<0.0001),\left(X^{2}=50.66 ; \mathrm{df}=3 ; p<0.0001\right),\left(X^{2}=23.84\right.$; $\mathrm{df}=3 ; \quad p<0.0001), \quad\left(X^{2}=16.86 ; \quad \mathrm{df}=3 ; \quad p=0.0008\right)$. There was no difference in the consumption of Kraussaria angulifera.

In the South Sudanian zone, there was a significant difference in the consumption of Gryllus campestris, Rhynchophorus phoenicis, and Macrotermes subhyalinus $\left(\left(X^{2}=40.14 ; \mathrm{df}=4 ; p<0.0001\right),\left(X^{2}=42.97 ; \mathrm{df}=4\right.\right.$; $\left.p<0.0001),\left(X^{2}=15.57 ; \mathrm{df}=4 ; p=0.0036\right)\right)$. No significant differences were found for Kraussaria angulifera, Cirina butyrospermi, and Oryctes sp.

The principal component analysis clearly showed that people from different villages had different preferences (Fig. 4). Kraussaria angulifera and Carbula marginella were the most cited in Mogtedo and Zitenga, Macrotermes subhyalinus was the most cited in Gampela and Kombissiri. Gryllus campestris and Oryctes sp. were the most cited in Dinderesso, Cirina butyrospermi was the most cited in
Koumi and Koro, and Rhynchophorus phoenicis was the most cited in Beregadougou and Siniena.

\section{Knowledge of edible insects among ethnic groups}

Macrotermes subhyalinus, Cirina butyrospermi, and Gryllus campestris were mentioned as edible insects by all nine ethnic groups whereas Kraussaria angulifera, Rhynchophorus phoenicis, Carbula marginella, and Oryctes sp. were cited by seven, five, two, and one ethnic groups, respectively (Table 4).

In the North Sudanian zone, there was no significant difference in the consumption of Cirina butyrospermi, Gryllus campestris, Carbula marginella, and Macrotermes subhyalinus among ethnic groups, whereas a significant difference $\left(X^{2}=5.49 ; \mathrm{df}=1 ; p=0.019\right)$ was found for Kraussaria angulifera which was highly preferred by the Mossi.

In the South Sudanian zone, the consumption of Gryllus campestris, Rhynchophorus phoenicis, Macrotermes subhyalinus, and Cirina butyrospermi was significantly different among ethnic groups $\left(\left(X^{2}=12.93\right.\right.$; $\mathrm{df}=6 ; p=0.04),\left(X^{2}=24.97 ; \mathrm{df}=6 ; p=0.0003\right),\left(X^{2}=20.76\right.$; $\left.\mathrm{df}=6 ; p=0.002),\left(X^{2}=16.63 ; \mathrm{df}=6 ; p=0.038\right)\right)$. That of Kraussaria angulifera and Oryctes sp. was not associated with the ethnic group. The principal component analysis clearly showed edible insect preference according to ethnic group (Fig. 5). Bobo, Guin, Sambla, Senoufo, and Turka ethnic groups preferentially mentioned Cirina butyrospermi while Macrotermes subhyalinus was the most mentioned by Fulani, Mossi, and Toussian ethnic groups. Oryctes sp. was cited only by the Toussian ethnic group.

\section{Knowledge of edible insects according to gender}

The preferences of edible insects varied according to gender (Fig. 6). Cirina butyrospermi, Macrotermes subhyalinus, Rhynchophorus phoenicis, and Carbula marginella were most cited by women whereas Gryllus campestris and Kraussaria angulifera were preferentially mentioned by men. Oryctes sp. was cited by both men and women in the same proportions.

\section{Seasonal occurrence, collection, and forms of consumption of edible insects}

The period of availability, collection techniques, and forms of consumption differed from one species to another (Table 5). The seasonal occurrence was related to

Table 2 Percentage of citations of species by phytogeographical zone

\begin{tabular}{|c|c|c|c|c|c|c|c|}
\hline $\begin{array}{l}\text { Phytogeographical } \\
\text { zones }\end{array}$ & $\begin{array}{l}\text { Macrotermes } \\
\text { subhyalinus }\end{array}$ & $\begin{array}{l}\text { Cirina } \\
\text { butyrospermi }\end{array}$ & $\begin{array}{l}\text { Kraussaria } \\
\text { angulifera }\end{array}$ & $\begin{array}{l}\text { Gryllus } \\
\text { campestris }\end{array}$ & $\begin{array}{l}\text { Carbula } \\
\text { marginella }\end{array}$ & $\begin{array}{l}\text { Rhynchophorus } \\
\text { phoenicis }\end{array}$ & Oryctes sp. \\
\hline South Sudanian & $62.5^{\mathrm{a}}$ & $81.00^{\mathrm{a}}$ & $21.00^{a}$ & $22.5^{a}$ & $0.00^{a}$ & $12.5^{a}$ & $1.00^{a}$ \\
\hline North Sudanian & $85.00^{b}$ & $4.37^{b}$ & $64.37^{b}$ & $13.13^{b}$ & $38.75^{b}$ & $0.00^{b}$ & $0.00^{a}$ \\
\hline
\end{tabular}

The citation percentages of the same column bearing different letters are significantly different $(p<0.05)$ 
Table 3 Percentage of citations of edible insect species by village

\begin{tabular}{|c|c|c|c|c|c|c|c|c|}
\hline $\begin{array}{l}\text { Phytogeographical } \\
\text { zones }\end{array}$ & Villages & $\begin{array}{l}\text { Macrotermes } \\
\text { subhyalinus }\end{array}$ & $\begin{array}{l}\text { Cirina } \\
\text { butyrospermi }\end{array}$ & $\begin{array}{l}\text { Kraussaria } \\
\text { angulifera }\end{array}$ & $\begin{array}{l}\text { Gryllus } \\
\text { campestris }\end{array}$ & $\begin{array}{l}\text { Carbula } \\
\text { marginella }\end{array}$ & $\begin{array}{l}\text { Rhynchophorus } \\
\text { phoenicis }\end{array}$ & Oryctes sp \\
\hline South Sudanian & Beregadougou & 50.00 & 95.00 & 17.50 & 7.50 & 0.00 & 30.00 & 0.00 \\
\hline South Sudanian & Dinderesso & 85.00 & 85.00 & 35.00 & 50.00 & 0.00 & 0.00 & 5.00 \\
\hline South Sudanian & Koro & 62.50 & 75.00 & 10.00 & 10.00 & 0.00 & 0.00 & 0.00 \\
\hline South Sudanian & Koumi & 67.50 & 77.50 & 25.00 & 40.00 & 0.00 & 0.00 & 0.00 \\
\hline South Sudanian & Siniena & 47.50 & 72.50 & 20.00 & 5.00 & 0.00 & 32.50 & 0.00 \\
\hline North Sudanian & Gampela & 72.50 & 0.00 & 62.50 & 32.50 & 25.00 & 12.50 & 0.00 \\
\hline North Sudanian & Kombissiri & 92.50 & 17.50 & 65.00 & 17.50 & 2.50 & 0.00 & 0.00 \\
\hline North Sudanian & Mogtedo & 100.00 & 0.00 & 60.00 & 0.00 & 75.00 & 0.00 & 0.00 \\
\hline North Sudanian & Zitenga & 75.00 & 0.00 & 70.00 & 2.50 & 52.50 & 0.00 & 0.00 \\
\hline
\end{tabular}

seasonal conditions. Macrotermes subhyalinus, Cirina butyrospermi, and Oryctes sp. occurred during the rainy season whereas Carbula marginella (Thunberg), Gryllus campestris, Kraussaria angulifera, and Rhynchophorus phoenicis occurred during the dry season. Collection techniques were specific to species. Children were involved in the collection of all species. Women specifically picked up Macrotermes subhyalinus, Cirina butyrospermi, and Carbula marginella. Men preferentially harvested Gryllus campestris and Kraussaria angulifera. Both women and men were involved in the collection of Rhynchophorus phoenicis. The consumption form common to all species is fried, followed by roasted (Macrotermes subhyalinus, Rhynchophorus phoenicis, and Oryctes sp.) and grilled (Kraussaria angulifera and Gryllus campestris). All species were indifferently consumed by children, women, and men without regard to their ages.

\section{Discussion}

\section{Distribution of cited edible insects according to} phytogeographical zone and villages

The number of edible insects (seven species) in the current study was less than those reported from other African countries. Takeda [41] reported 21 species consumed by the Ngandu people in the Democratic Republic of Congo. Malaisse [42] inventoried 30 edible species in northern Zambia, RDC and northeastern Zimbabwe. Obopile and Seeletso [43] identified 27 edible insects in Botswana. Twenty-two (22) insect species belonging to six different orders have been recorded with potential for consumption among the three major ethnic groups (Yoruba, Hausa, and Ibo) in Nigeria [12].

Kraussaria angulifera, Cirina butyrospermi, Gryllus campestris, Macrotermes subhyalinus, Oryctes sp., and Rhynchophorus phoenicis have already been reported as

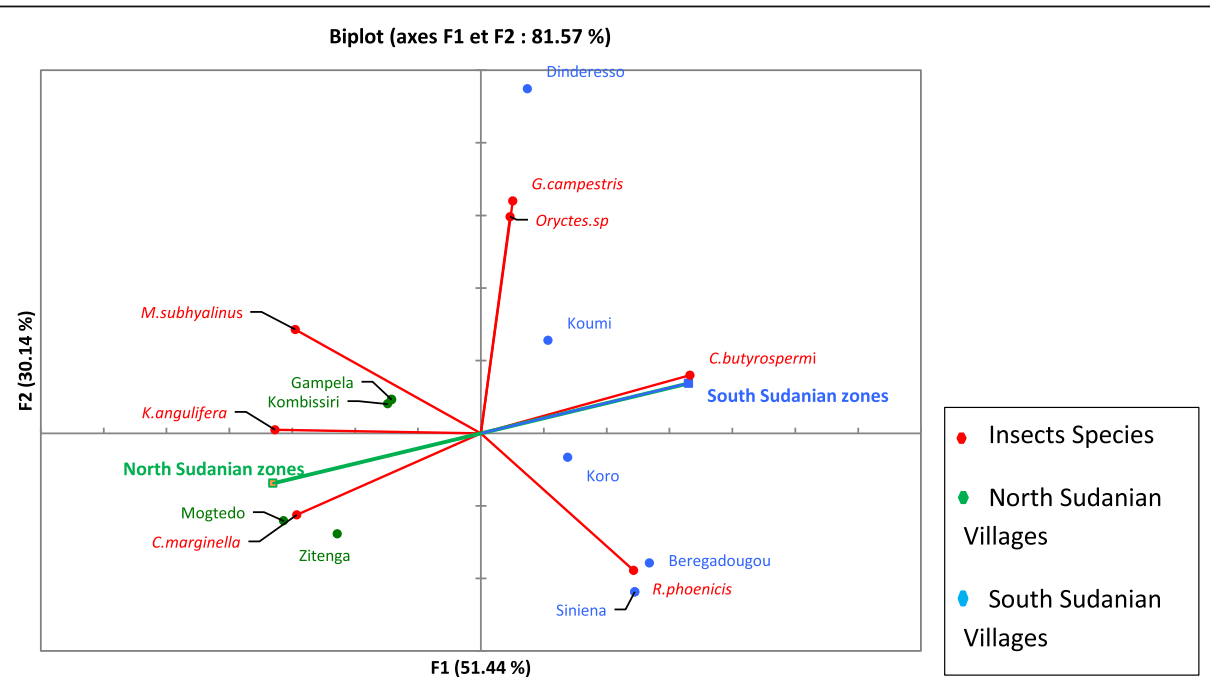

Fig. 4 Principal component analysis (PCA) of the preference for consumption of edible insects in nine villages and two phytogeographical zones of Burkina Faso 
Table 4 Percentage of citations of edible insect species by ethnic group

\begin{tabular}{|c|c|c|c|c|c|c|c|}
\hline Ethnic groups & $\begin{array}{l}\text { Macrotermes } \\
\text { subhyalinus }\end{array}$ & $\begin{array}{l}\text { Cirina } \\
\text { butyrospermi }\end{array}$ & $\begin{array}{l}\text { Kraussaria } \\
\text { angulifera }\end{array}$ & $\begin{array}{l}\text { Gryllus } \\
\text { campestris }\end{array}$ & $\begin{array}{l}\text { Carbula } \\
\text { marginella }\end{array}$ & $\begin{array}{l}\text { Rhynchophorus } \\
\text { phoenicis }\end{array}$ & Oryctes sp. \\
\hline Bobo & 63.26 & 81.63 & 16.32 & 30.61 & 0.00 & 0.00 & 0.00 \\
\hline Fulani & 85.71 & 7.14 & 35.71 & 0.00 & 28.57 & 0.00 & 0.00 \\
\hline Guin & 41.67 & 79.16 & 20.83 & 8.33 & 0.00 & 29.16 & 0.00 \\
\hline Mossi & 79.67 & 18.13 & 57.14 & 15.93 & 31.87 & 2.20 & 0.00 \\
\hline Sambla & 50.00 & 91.67 & 0.00 & 16.67 & 0.00 & 16.66 & 0.00 \\
\hline Senoufo & 66.67 & 91.67 & 8.33 & 20.83 & 0.00 & 16.67 & 0.00 \\
\hline Toussian & 96.43 & 71.43 & 57.14 & 39.28 & 0.00 & 0.00 & 7.14 \\
\hline Turka & 51.85 & 85.18 & 22.22 & 7.41 & 0.00 & 29.63 & 0.00 \\
\hline
\end{tabular}

edible insect species in different parts of Africa. However, to the best of our knowledge, this study is the first report on Carbula marginella as an edible insect. No prohibition regarding any species has been noted during the survey in contrast to that reported in Nigeria [44].

Each species develops only under specific climatic conditions. Cirina butyrospermi and Oryctes sp. reproduce exclusively in the south Sudanian zone under specific rainfall (900 to $1000 \mathrm{~mm}$ ) and humidity conditions [37]. Rhynchophorus phoenicis was available in the South Sudanian zone. Cirina butyrospermi is dried and marketed throughout the country while the consumption of Oryctes sp. and Rhynchophorus phoenicis was restricted to the South Sudanian zone. Carbula marginella was found only in the northern Sudanian area. Its consumption is restricted to its production zone due to the absence of a trade system. Gryllus campestris and Macrotermes subhyalinus were available in both South and North Sudanian zones where they are well consumed. Macrotermes subhyalinus is marketed throughout the country.

\section{Knowledge of edible insects among ethnic groups}

In addition to the availability, another parameter which influences species edibility is ethnic preference. All the eight ethnic groups were entomophagous. However, there are considerable differences in preferences among them. Similar results were reported in Benin where specific preferences were observed among several ethnic groups. In the South of Benin, the most consumed insects across different localities were the larvae of Oryctes sp. and Rhynchophorus phoenicis. On the contrary, in the North, an assemblage of more varied insect species was consumed across different localities [30]. Riggi et al. [30] linked the richness of edible insect species in the

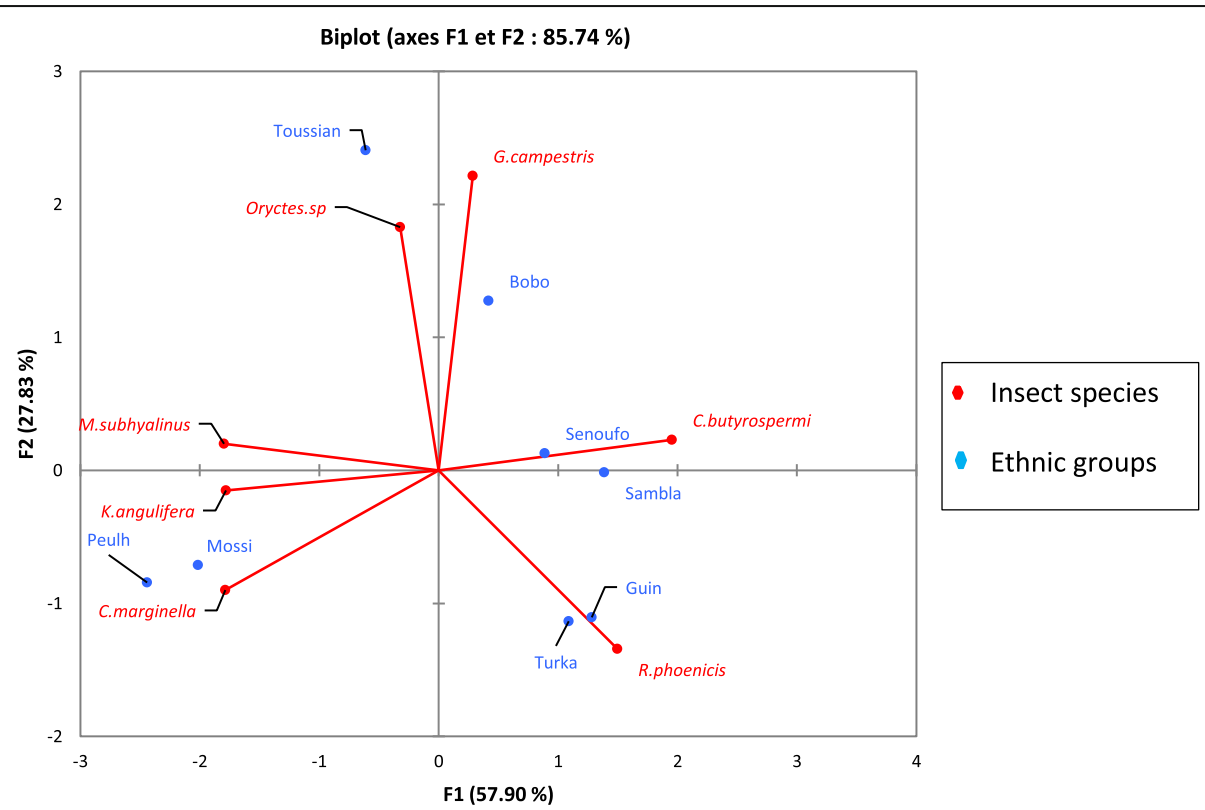

Fig. 5 Principal component analysis (PCA) of the preference for consumption of edible insects of ethnic groups in two phytogeographical zones of Burkina Faso 


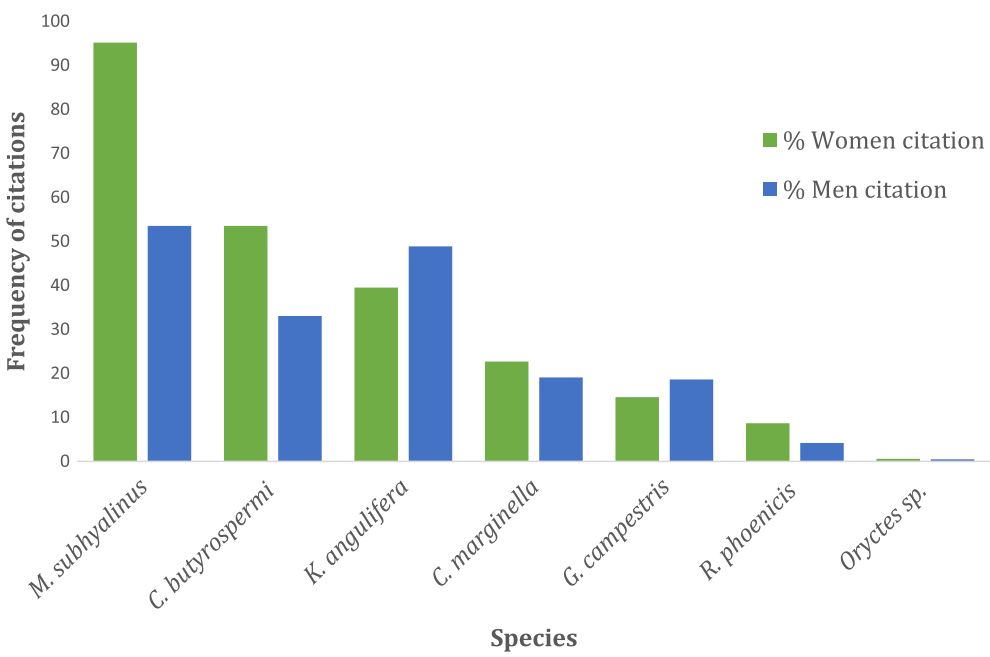

Fig. 6 Frequency of citations according to gender of nine edible insects of Burkina Faso

North of Benin to the poverty and the unreliable productivity of agriculture in this region. Observation on the distribution and consumption of edible insects in Nigeria revealed that the practice of entomophagy is common in the humid forest, derived savanna, and some parts of Southern Guinea Savanna agro-ecological zones of the country [12]. In Burkina Faso, the high diversity of edible insects was observed in the South Sudanian zone which is known as the agricultural belt of the country. Diversity of consumed insects seems therefore to be more linked to species availability and people's alimentary habits and culture. These factors could explain why the Waama ethnic group in Benin only eat the adult and not the larvae of Lepidoptera, such as Cirina butyrospermi [30]. In the same way, the Mofu-Gudur in Cameroon eat a number of grasshopper species (Acorypha picta, A. glaucopsis, Acrida bicolor, Oedaleus senegalensis (Krauss, 1877), Pyrgomorpha cognate (Krauss, 1877), Truxalis johnstoni (Dirsh, 1951)), which are not eaten by the Hausa in Niger, and vice versa (Humbe tenuicornis (Schaum, 1853)) [32, 33]. Change in alimentary habit and culture could also explain why Mossi and Fulani ethnic migrants in the South Sudanese zone eat Cirina butyrospermi whereas members of the same ethnic groups in the North Sudanian zone do not. One consequence of such differences in preferred species, as explained by Meyer-Rochow [45], is that pressure on a resource is distributed across a range of species and in this way it helps to avoid an overexploitation of the resource. In the same line, species availability, alimentary habit, and culture could also explain the restriction of the consumption of Oryctes sp. and Carbula marginella to specific zones and ethnic groups of Burkina Faso.

Table 5 Seasonal occurrence, collection, and forms of consumption of edible insects

\begin{tabular}{|c|c|c|c|c|c|c|c|}
\hline Scientific name & Orders & $\begin{array}{l}\text { Common } \\
\text { name }\end{array}$ & Seasonal availability & $\begin{array}{l}\text { Consumption } \\
\text { stage }\end{array}$ & Methods of collection & $\begin{array}{l}\text { Person who } \\
\text { collect }\end{array}$ & $\begin{array}{l}\text { Forms of } \\
\text { consumption }\end{array}$ \\
\hline $\begin{array}{l}\text { Macrotermes } \\
\text { subhyalinus }\end{array}$ & Isoptera & Winged termites & June-July & Adult & $\begin{array}{l}\text { Trapped in a large bowl } \\
\text { of water near the light } \\
\text { source }\end{array}$ & Children, women & Fried, roasted \\
\hline $\begin{array}{l}\text { Cirina } \\
\text { butyrospermi }\end{array}$ & Lepidoptera & Caterpillar & June-August & Larva & $\begin{array}{l}\text { Picked up under the } \\
\text { plant }\end{array}$ & Children, women & $\begin{array}{l}\text { Fried, ingredients } \\
\text { in sauce }\end{array}$ \\
\hline $\begin{array}{l}\text { Kraussaria } \\
\text { angulifera }\end{array}$ & Orthoptera & Grasshopper & November-January & Adult & $\begin{array}{l}\text { Harvested by hand or } \\
\text { with a stick very early } \\
\text { in the morning }\end{array}$ & Men, children & Fried, grilled \\
\hline $\begin{array}{l}\text { Gryllus } \\
\text { campestris }\end{array}$ & Orthoptera & Field cricket & September-October & Adult & $\begin{array}{l}\text { Hunted by digging them } \\
\text { out from their burrows }\end{array}$ & Men, children & Fried, grilled \\
\hline $\begin{array}{l}\text { Carbula } \\
\text { marginella }\end{array}$ & Hemiptera & Beetle & October-January & Adult & $\begin{array}{l}\text { Picked up under the } \\
\text { cave holes and millet }\end{array}$ & Children, women & Fried \\
\hline $\begin{array}{l}\text { Rhynchophorus } \\
\text { phoenicis }\end{array}$ & Coleoptera & Palm weevil & December-May & Larva & $\begin{array}{l}\text { Picked up inside the } \\
\text { infested host plant }\end{array}$ & $\begin{array}{l}\text { Children, men, } \\
\text { women }\end{array}$ & Fried, roasted \\
\hline Oryctes sp. & Coleoptera & - & June-August & Larva & $\begin{array}{l}\text { Picked in the cow } \\
\text { dung }\end{array}$ & Children, women & Fried, roasted \\
\hline
\end{tabular}




\section{Knowledge of edible insects according to gender}

Women and children are most involved in insect collection. Women are the main actors in the collection and sale of edible insects. In southern Zimbabwe, the collection, processing, and marketing of mopane caterpillars (Imbrasia belina (Westwood, 1849)) were traditionally practiced by women $[46,47]$. This activity generates income for these women and their families. These incomes are used for food, child rearing, and other family expenses $[48,49]$.

\section{Seasonal occurrence, collection, and forms of consumption of edible insects}

As reported, the seasonal availability is mostly influenced by environmental factors such as temperature and relative humidity. On this basis, two groups of species can be distinguished: rainy season species (Macrotermes subhyalinus, Cirina butyrospermi, and Oryctes sp.) and dry season species (Carbula marginella, Gryllus campestris, Kraussaria angulifera, and Rhynchophorus phoenicis). In addition to these factors, host availability is another key factor for some species. Thus, the availability of Cirina butyrospermi is close to the availability of its host shea tree. Women and children are once again the main edible insect collectors. The collection methods can be grouped in easy (by hand) and hard collecting methods (digging in the soil). Species can also be classified in income-generating (Macrotermes subhyalinus, Cirina butyrospermi, Carbula marginella) and non-income-generating species (Gryllus campestris, Rhynchophorus phoenicis, Kraussaria angulifera, and Oryctes sp.). Women are mostly involved in easy-to-collect and income-generating species. Children and men are dominant collectors when physical effort is required. There is a diversity in the methods of preparation. Hongbété and Kindossi [50] reported that the edible insects were sun-dried, fried, and smoked or roasted. In some cases, edible insects are used as condiment in slimy and vegetable sauces [50]. Chakravorty et al. [51] reported also that short-horned grasshoppers (Acrididae) are fried.

Riggi et al. [52] reported that in the Northern Benin, children between 5 and 15 years of age chased in groups edible insects that they collected in a jar, cooked in a pan with shea butter, or grilled directly on charcoal. The larva of Oryctes monoceros is boiled, smoked, or fried [53]. The Bambaras in Mali and Burkina Faso fried Cirina forda in shea tree [54]. R. phoenicis is often grilled or fried on charred coals [55].

\section{Conclusion}

Our survey revealed seven edible insect species in the nine villages studied. The knowledge of edible species varied from one locality to another and between ethnic groups. Cirina butyrospermi, Oryctes sp., Rhynchophorus phoenicis, and Gryllus campestris were the most cited in the South Sudanian zone, whereas Macrotermes subhyalinus, Carbula marginella, and Kraussaria angulifera were most cited in the North Sudanian zone. Bobo, Guin, Sambla, Senoufo, and Turka ethnic groups mentioned Cirina butyrospermi as the preferred species, but Fulani, Mossi, and Toussian preferred Macrotermes subhyalinus. Oryctes sp. was cited only by the Toussian ethnic group. As insects are used and appreciated as food in Burkina Faso, there is considerable potential to further develop this commodity.

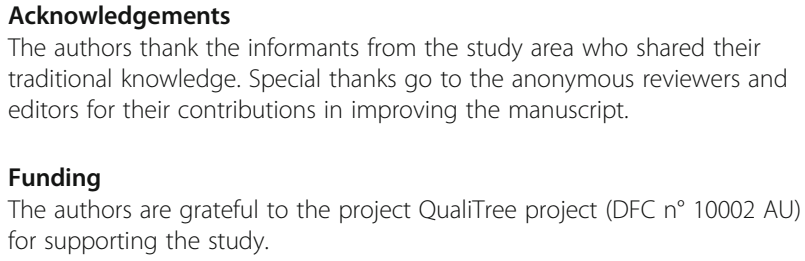

Funding

The authors are grateful to the project QualiTree project (DFC n $10002 \mathrm{AU}$ ) for supporting the study.

\section{Availability of data and materials}

Samples of the insects were deposited in the Département de Biochimie Microbiologie of the Université Ouaga I Professeur Joseph KI-Zerbo.

\section{Authors' contributions \\ $A S, A B, T J O, H S, O G$, and IHNB conceived and designed the experiment study and performed the study. AS, $A B, H S, A M L, A O, O G$, and $I H N B$ analyzed the data. AS, OG, AB, JTO, MT, HS, AML, AO, and IHNB wrote the paper. All authors read and approved the final manuscript.}

Ethics approval and consent to participate

Not applicable

\section{Consent for publication}

Not applicable

\section{Competing interests}

The authors declare that they have no competing interests.

\section{Publisher's Note}

Springer Nature remains neutral with regard to jurisdictional claims in published maps and institutional affiliations.

\section{Author details}

1Département de Biochimie Microbiologie, Université Ouaga I Professeur Joseph KI-Zerbo, 03 BP 7021, Ouagadougou 03, Burkina Faso. ²Département Productions Forestières, Institut de I'Environnement et de Recherches Agricoles (INERA), 03 BP 7047, Ouagadougou 03, Burkina Faso. ³ Department of Bioscience, Aarhus University, Vejlsøvej 25, 8600 Silkeborg, Denmark. ${ }^{4}$ Département de biologie et physiologie végétale, Université Ouaga I Professeur Joseph KI-Zerbo, 03 BP 7021, Ouagadougou 03, Burkina Faso. ${ }^{5}$ Département de biologie et physiologie animales, Université Ouaga I Professeur Joseph KI-Zerbo, 03 BP 7021, Ouagadougou 03, Burkina Faso.

Received: 12 February 2018 Accepted: 29 August 2018

Published online: 14 September 2018

References

1. Alexandratos N, Bruinsma J. World agriculture towards 2030/2050: the 2012 revision. In: ESA working paper FAO, Rome; 2012.

2. Pan A, Sun Q, Bernstein AM, Schulze MB, Manson JE, Stampfer MJ, Willett WC, Hu FB. Red meat consumption and mortality: results from 2 prospective cohort studies. Arch Intern Med. 2012;172(7):555-63.

3. King D, Peckham C, Waage J, Brownlie J, Woolhouse ME. Infectious diseases: preparing for the future. Science. 2006;313(5792):1392-3. 
4. Jongema, Y. List of edible insects of the world. 2018. https://www.wur.nl/ en/Research-Results/Chair-groups/Plant-Sciences/Laboratory-of-Entomology/ Edible-insects/Worldwide-species-list.htm. Accessed 15 July 2018.

5. Nakagaki BJ, Defoliart GR. Comparison of diets for mass-rearing Acheta domesticus (Orthoptera: Gryllidae) as a novelty food, and comparison of food conversion efficiency with values reported for livestock. J Econ Entomol. 1991;84(3):891-6.

6. van Huis A, Van Itterbeeck J, Klunder H, Mertens E, Halloran A, Muir G, Vantomme P. Edible insects: future prospects for food and feed security. Rome: Food and Agriculture Organization of the United Nations; 2013.

7. Koneswaran G, Nierenberg D. Global farm animal production and global warming: impacting and mitigating climate change. Environ Health Perspect. 2008;116(5):578-82.

8. Thornton PK. Livestock production: recent trends, future prospects. Philos Trans R Soc B. 2010;365(1554):2853-67.

9. Grabowski NT, Klein G. Bacteria encountered in raw insect, spider, scorpion, and centipede taxa including edible species, and their significance from the food hygiene point of view. Trends Food Sci Technol. 2017;63:80-90.

10. Van Huis A. Potential of insects as food and feed in assuring food security. Annu Rev Entomol. 2013;58:563-83.

11. Rumpold BA, Schlüter OK. Nutritional composition and safety aspects of edible insects. Mol Nutr Food Res. 2013;57(5):802-23.

12. Alamu O, Amao A, Nwokedi C, Oke O, Lawa I. Diversity and nutritional status of edible insects in Nigeria: a review. Int J Biodivers Conserv. 2013;5(4):215-22.

13. Okunowo W, Olagboye A, Afolabi L, Oyedeji A. Nutritional value of Rhynchophorus phoenicis (F.) larvae, an edible insect in Nigeria. Afr Entomol. 2017;25(1):156-63.

14. Dué EA, Zabri HCB, Kouadio JPE, Kouame LP. Fatty acid composition and properties of skin and digestive fat content oils from Rhynchophorus palmarum L. larva. Afr J Biochem Res. 2009;3(4):089-94.

15. Chakravorty J, Ghosh S, Megu K, Jung C, Meyer-Rochow VB. Nutritional and anti-nutritional composition of Oecophylla smaragdina (Hymenoptera: Formicidae) and Odontotermes sp.(Isoptera: Termitidae): two preferred edible insects of Arunachal Pradesh, India. J Asia-Pacif Entomol. 2016; 19(3):711-20.

16. Chakravorty J, Ghosh S, Jung C, Meyer-Rochow V. Nutritional composition of Chondacris rosea and Brachytrupes orientalis: two common insects used as food by tribes of Arunachal Pradesh, India. J Asia-Pacif Entomol. 2014; 17(3):407-15.

17. Omotoso O. Nutritional quality, functional properties and anti-nutrient compositions of the larva of Cirina forda (Westwood) (Lepidoptera: Saturniidae). J Zhejiang Univ Sci B. 2006;7(1):51-5.

18. Payne CL, Scarborough P, Rayner M, Nonaka K. A systematic review of nutrient composition data available for twelve commercially available edible insects, and comparison with reference values. Trends Food Sci Technol. 2016:47:69-77.

19. Paiko YB, Jacob JO, Salihu SO, Dauda BE, Suleiman MA, Akanya HO. Fatty acid and amino acid profile of emperor moth caterpillar (Cirina forda) in Paikoro Local Government Area of Niger State, Nigeria. Amer J Biochem. 2014;4(2):29-34.

20. Kinyuru JN, Konyole SO, Roos N, Onyango CA, Owino VO, Owuor BO, Estambale BB, Friis H, Aagaard-Hansen J, Kenji GM. Nutrient composition of four species of winged termites consumed in western Kenya. J Food Compos Anal. 2013;30(2):120-4

21. Ghosh S, Jung C, Meyer-Rochow VB. Nutritional value and chemical composition of larvae, pupae, and adults of worker honey bee, Apis mellifera ligustica as a sustainable food source. J Asia-Pacif Entomol. 2016;19(2):487-95.

22. Igwe C, Ujowundu C, Nwaogu L, Okwu G. Chemical analysis of an edible African termite Macrotermes nigeriensis, a potential antidote to food security problem. Biochem Anal Biochem. 2011;1(1):105.

23. Schabel HG. Forest insects as food: a global review. Forest insects as food: humans bite back; 2010. p. 37-64.

24. Banjo A, Lawal O, Songonuga E. The nutritional value of fourteen species of edible insects in southwestern Nigeria. Afr J Biotechnol. 2006;5(3):298-301.

25. Christensen DL, Orech FO, Mungai MN, Larsen T, Friis H, Aagaard-Hansen J. Entomophagy among the Luo of Kenya: a potential mineral source? Int J Food Sci Nutr. 2006;57(3-4):198-203.

26. Durst PB, Johnson DV, Leslie RN, Shono K. Forest insects as food: humans bite back. Bangkok: FAO Regional Office for Asia and the Pacific; 2010 http://www.fao.org/docrep/012/i1380e/i1380e00.pdf
27. Ramos-Elorduy J. Anthropo-entomophagy: cultures, evolution and sustainability. Entomol Res. 2009;39(5):271-88.

28. Ramos-Elorduy J. Insects: a hopeful food source. In: Paoletti MG, editor. Ecological implications of minilivestock. Enfield: Science Pub; 2005. p. 263-91.

29. Roulon-Doko P. Chasse, cueillette et cultures chez les Gbaya de Centrafrique. Paris: L'Harmattan; 1998.

30. Riggi L, Veronesi M, Goergen G, MacFarlane C, Verspoor R. Observations of entomophagy across Benin-practices and potentials. Food Sec. 2016;8(1): 139-49.

31. Ehounou G, Ouali-N'goran S, Niassy S. Assessment of entomophagy in Abidjan (Cote Divoire, West Africa). Afr J Food Sci. 2018;12(1):6-14.

32. Luxereau A. Notes sur quelques criquets de la région de Maradi (Niger) et leurs noms Hausa. J Agric Trad Bot Appl. 1980;27(3):263-72.

33. Barreteau D. Les Mofu-Gudur et leurs criquets. In: Baroin C, Boutrais J, editors. L'homme et I'animal dans le bassin du lac Tchad. Paris: Collection Colloques et Seminaires; 1999. p. 133-69.

34. Kelemu S, Niassy S, Torto B, Fiaboe K, Affognon H, Tonnang H, Maniania N, Ekesi S. African edible insects for food and feed: inventory, diversity, commonalities and contribution to food security. J Insects Food Feed. 2015; 1(2):103-19.

35. Fontès J, Guinko S. Carte de la végétation et de l'occupation du sol du Burkina Faso: notice explicative. Toulouse: Ministère de la coopération Française 66p; 1995. p. 1.

36. Paré $S$, Savadogo $P$, Tigabu M, Ouadba JM, Odén PC. Consumptive values and local perception of dry forest decline in Burkina Faso, West Africa. Environ Dev Sustain. 2010;12(2):277-95.

37. Zampaligré N, Dossa LH, Schlecht E. Climate change and variability: perception and adaptation strategies of pastoralists and agropastoralists across different zones of Burkina Faso. Reg Environ Chang. 2014;14(2):769-83.

38. Sambaré O, Bognounou F, Wittig R, Thiombiano A. Woody species composition, diversity and structure of riparian forests of four watercourses types in Burkina Faso. J For Res. 2011;22(2):145-58.

39. Barthelemy Y, Tyano A, Bationo BA, Ouattara B, Koala J, Rasolodimby JM. Effects of Piliostigma reticulatum on the vegetation dynamic in Sudanian Zone of Burkina Faso. J Plant Studies. 2017;6(2):77.

40. Scholtz $\mathrm{CH}$. The higher classification of southern African insects. Afr Entomol. 2016;24(2):545-55.

41. Takeda J. The dietary repertory of the Ngandu people of the tropical rain forest: an ecological and anthropological study of the subsistence activities and food procurement technology of a slash-and-burn agriculturist in the Zaire river basin. Afr Study Monogr. 1990;11(Suppl):1-75.

42. Malaisse F. Food supply in African open forests: an ecological and nutritional approach. Se nourrir en foret claire africaine: Approche ecologique et nutritionnelle. Gembloux: Les Presses Agronomiques de Gembloux; 1997.

43. Obopile M, Seeletso TG. Eat or not eat: an analysis of the status of entomophagy in Botswana. Food Sec. 2013;5(6):817-24.

44. Fasoranti JO, Ajiboye DO. Some edible insects of Kwara State, Nigeria. Am Entomol. 1993;39:113-6.

45. Meyer-Rochow VB. Food taboos: their origins and purposes. J Ethnobiol Ethnomed. 2009;5(1):18.

46. Hobane PA. The urban marketing of the mopane worm: the case of Harare. CASS - NRM Occasional Paper Series. Mt Pleasant, Harare. Harare: Centre for Appled Social Sciences (CASS); 1994.

47. Kozanayi W, Frost P. Marketing of mopane worm in Southern Zimbabwe. Mopane worm market survey: Southern Zimbabwe. Harare: Institute of Environmental Studies; 2002. p. 31.

48. Agea JG, Biryomumaisho D, Buyinza M, Nabanoga GN. Commercialization of Ruspolia nitidula (nsenene grasshoppers) in Central Uganda. Afr J Food Agric Nutr Dev. 2008;8(3):319-32.

49. Hope RA, Frost PG, Gardiner A, Ghazoul J. Experimental analysis of adoption of domestic mopane worm farming technology in Zimbabwe. Dev South Afr. 2009;26(1):29-46.

50. Hongbété $F$, Kindossi J. Diversity and traditional consumption of edible insects in North Benin. J Sci Res Rep. 2017;14(1):1-11.

51. Chakravorty J, Ghosh S, Meyer-Rochow VB. Practices of entomophagy and entomotherapy by members of the Nyishi and Galo tribes, two ethnic groups of the state of Arunachal Pradesh (North-East India). J Ethnobiol Ethnomed. 2011;7(1):5. 
52. Riggi L, Veronesi M, Verspoor R, MacFarlane C, Tchibozo S. Exploring entomophagy in Northern Benin: practices, perceptions and possibilities Book of Abstracts of Conference on Insects to Feed the World, The Netherlands; 2014. p. 14-7.

53. Ifie I, Emeruwa C. Nutritional and anti-nutritional characteristics of the larva of Oryctes monoceros. Agric Biol J N Am. 2011;2(1):42-6.

54. Bergier E. Insectes comestibles et peuples entomophages. Avignon: Ruillere; 1941

55. Van Huis A. Insects as food in sub-Saharan Africa. Int J Trop Insect Sci. 2003; 23(3):163-85.

Ready to submit your research? Choose BMC and benefit from:

- fast, convenient online submission

- thorough peer review by experienced researchers in your field

- rapid publication on acceptance

- support for research data, including large and complex data types

- gold Open Access which fosters wider collaboration and increased citations

- maximum visibility for your research: over $100 \mathrm{M}$ website views per year

At $\mathrm{BMC}$, research is always in progress.

Learn more biomedcentral.com/submissions 